\title{
Semi-purified Fraction of Clinacanthus nutans Induced Apoptosis in Human Cervical Cancer, SiHa Cells via Up-regulation of Bax and Down-regulation of Bcl-2 (Fraksi Separa Tulen Clinacanthus nutans Teraruh Apoptosis pada Kanser Pangkal Rahim Manusia, Sel-sel SiHa melalui Kawal Atur-atas Bax dan Kawal Atur-bawah Bcl-2)
}

\author{
NiK Aina SyAZANA NiK ZAINUdDIn, HuSSIN MUHAMMAD, NiK FAKHURUdDIN NIK HASSAN, \\ NOR HAYATI OTHMAN \& YUSMAZURA ZAKARIA*
}

\begin{abstract}
Cervical cancer is a leading cause of death in women, worldwide, and second in Malaysia. Nowadays, modern cancer treatment comes with negative and adverse side effects to the patients. Traditional medicinal plants such as Clinacanthus nutans has been locally recognized for its medicinal properties and was claimed for cancer treatment. According to our pilot study, a fraction of $\mathrm{C}$. nutans has shown a potent inhibition on human cervical cancer cells, SiHa, in vitro. Hence, this study aimed to investigate the underlying anticancer mechanism of a semi-purified fraction (SF1) of C. nutans towards cervical cancer cells. Bioassay guided fractionation and further purification was carried out. All collected fractions of C. nutans were examined for cytotoxicity activity towards HeLa, SiHa and NIH cells by MTT Assay. SFl exhibited better cytotoxic activity with best growth inhibition against SiHa cells $\left(I_{50}\right.$ value $\left.=9.60 \mu \mathrm{g} / \mathrm{mL}\right)$. Cytoselective effects were shown as no cytotoxicity observed in the treated normal NIH cells. SF1 induced early apoptosis event in SiHa cells as resulted by FITC-Annexin V/propidium iodide staining by flowcytometric analysis. The protein expression by flowcytometry using specific antibody conjugated fluorescent dye showed up-regulation of Bax and down-regulation Bcl-2 as well as increment of cytochrome C levels upon treatment with SF1. In conclusion, the findings suggested that SF1 demonstrated antiproliferative effects and induced apoptosis in SiHa cells through up-regulation of Bax and down-regulation of Bcl-2 via mitochondrial-dependent pathway.
\end{abstract}

Keywords: Apoptosis; cervical cancer; Clinacanthus nutans

\section{ABSTRAK}

Kanser pangkal rahim adalah penyebab utama kematian wanita di seluruh dunia dan kedua di Malaysia. Pada masa ini, rawatan moden kanser banyak memberi kesan negatif kepada pesakit. Tumbuhan ubatan tradisi seperti Clinacanthus nutans telah dikenal pasti dan dipercayai oleh penduduk tempatan sebagai alternatif kepada rawatan kanser. Menurut kajian awal kami, satu fraksi daripada C. nutans telah menunjukkan perencatan yang aktif terhadap kanser serviks manusia, secara in vitro. Oleh itu, penyelidikan ini bertujuan untuk mengkaji mekanisme antikanser oleh fraksi separapenulenan, SF1 daripada C. nutans terhadap kanser serviks. Penfraksian berpandukan bioaktiviti dan penulenan lanjutan telah dijalankan. Semua fraksi yang terkumpul daripada C. nutans telah diuji untuk aktiviti kesitoksikan terhadap sel HeLa, SiHa dan NIH oleh asai MTT. SFl menunjukkan aktiviti sitotoksik yang lebih baik dengan antiproliferasi paling berpotensi terhadap sel SiHa (nilai $I_{50}=9.60 \mu \mathrm{g} / \mathrm{mL}$ ) dan menunjukkan kesan sitomemilih terhadap sel normal, $\mathrm{NIH}$. Kesan apoptosis awal dapat diaruhkan terhadap sel SiHa daripada rawatan SF1 melalui analisis flositometri oleh pewarnaan FITC-Annexin V/propidium iodida. Pengekspresan protein menggunakan antibodi khusus berkonjugasi pendarfluor oleh analisis flositometri juga menunjukkan pengawalaturan Bax dan Bcl-2 serta peningkatan kadar sitokrom $C$ setelah dirawat dengan SF1. Kesimpulannya, SF1 menunjukkan kesan antiproliferatif dan apoptosis yang diaruhkan dalam sel SiHa melalui pengawalaturan Bax dan Bcl-2.

Kata kunci: Apoptosis; Clinacanthus nutans; kanser serviks

\section{INTRODUCTION}

Cancer has been one of the major health threats in this world. In 2017, International Agency Research on Cancer (IARC), the specialized cancer agency of the World Health Organization (WHO) in its online database, GLOBOCAN, reported that more than 14 million new cancer cases and almost 10 million cancer-related deaths. GLOBOCAN also reported that cancer of the cervix uteri is the fourth most common cancer among women worldwide (Bruni et al. 2018). National Cancer Society of Malaysia (NCSM) reported that cervical cancer is the second most common cancer among women and the fourth leading cause of death in women aged between 15 and 44 years old, in Malaysia (Indramalar 2015). Among major factor contributing to cervical cancers is human papilloma virus (HPVs) such as HPV 16, 18 and 31. However, $70 \%$ of the 
cervical cancers comprises from HPV 16 and HPV 18 (Choudari et al. 2013).

Among current treatment of cervical cancer are surgery and radiotherapy together with chemotherapy. Those treatment has remained first-line option to treat cervical cancer. However, the approach was limited by resistance, toxicity to surrounding healthy cells in body and expensive operation. Nowadays, many anticancer drugs have been developed by utilizing medicinal plants in both traditional and modern medicine (Ghasemzadeh et al. 2014). Usage of herbal medicine in cancer treatment has been used extensively by many Malaysian old folks to improve survivorship. Herbal medicine has been an asset to Malaysian due to richness of our herbal resources (Ch'ng et al. 2016). In developing countries such as Malaysia, $85 \%$ of people utilized traditional medicines derived from herbal plants for their primary health care (World Health Organization 2016). This positive trend could be due to insensitivity towards commercial anticancer drugs and existence of unwanted side effects of current cancer treatment. Therefore, new and safe drugs that originated from herbal plants are necessary in order to improve standard treatments, in vitro and in vivo.

Clinacanthus nutans or commonly known as Sabah Snake Grass or Belalai Gajah, is a medicinal plant native to the tropical Asia countries including China, Vietnam, Thailand, Malaysia and Indonesia (Huang et al. 2016; Le et al.2017).C. nutans belongs to family Acanthaceae. This type of plant grows easily in nearly every habitat such as open or dense forests in tropical areas. Traditionally, this plant has been used by local to treat dysentery, fever, viral infection, skin rashes and insect bites (Ghasemzadeh et al. 2014; Sulaiman et al. 2015). In Malaysia, the fresh leaves of $C$. nutans are consumed as a juice or herbal tea upon boiled with water (Alam et al. 2016). A few numbers of studies related to antiproliferative properties of $C$. nutans have been extensively described. Chloroform extract has been reported capable of scavenging free radical and inhibited the growth of cervical cancer, HeLa cells (Yong et al. 2013). Ethanol extract from the aerial part was reported could inhibit hepatoma in mice, indicated the potential antitumor and immunomodulatory properties of $C$. nutans (Huang et al. 2015). Same research group also attempted purification of a polysaccharide peptide complex from the $C$. nutans leaves, showed potential for gastric cells inhibition (Huang et al. 2016). Despite numerous identified studies related to antiproliferative activity of this plant, little information regarding its anticancer mechanism was reported. From our pilot study, a fraction of $C$. nutans named as F11 was found to be active towards human cervical carcinoma cell, HeLa and arrest cell cycle at G1/S phase (Roslan et al. 2018). Hence, the aim of the present study was to determine the cytotoxic effects and mechanism of cell death of a semi-purified fraction of $C$. nutans against human cervical carcinoma, in vitro.

\section{MATERIALS AND METHODS}

\section{COLLECTION AND AUTHENTICATION OF C. NUTANS}

The fresh parts including stem with leaves, shoots and branches of $C$. nutans (Burm.f.) Lindau were freshly collected from Pengkalan Chepa, Kelantan. The specimen was authenticated by botanist, Dr Shamsul Khamis, Herbarium Kulliyyah of Pharmacy, Universiti Islam Antarabangsa Malaysia (UIA). A voucher specimen of the C. nutans (No. PIIUM 0238-2) was prepared and deposited at the herbarium. The leaves were washed and dried in drying oven at $50^{\circ} \mathrm{C}$ for overnight. The dried leaves of $C$. nutans were ground to coarse powder using laboratory grinder.

\section{EXTRACTION, ISOLATION AND PURIFICATION OF C. nutans}

The dried powdered leaves were sequentially extracted with hexane and chloroform, respectively (Sakdarat et al. 2009). The extract was concentrated in vacuo at $40^{\circ} \mathrm{C}$ to yield dried chloroform extract. For isolation of $C$. nutans, the chloroform extract was initially chromatographed on a silica gel 60 (250 g) using column with dry vacuum liquid chromatographic technique. The column was eluted with hexane - ethyl acetate (1:1) in order to collect and isolate only the active fraction named as F11 (Roslan et al.2018). The fractions were collected by monitoring with thin-layer chromatography (TLC), chloroform - methanol (1:1). In order to further characterize the F11, purification of F11 were carried out by chromatographed on silica gel 60 (200 g) using dry vacuum liquid chromatographic technique. Approximately $2 \mathrm{~g}$ of F11 was loaded onto the column. The column was eluted with acetonitrile - methanol (2:8). A portion of each fraction was separated by preparative TLC chloroform - methanol (2:8) and retention factor (Rf) for each TLC plates were calculated as (distance moved by solute)/(distance moved by solvent).

\section{CYTOTOXICITY STUDIES}

In order to determine the potent cell inhibition property, all collected fractions were examined for cytotoxicity activity towards two types of human cervix carcinoma cell lines (HeLa cells and SiHa cells) and normal fibroblast cell line (NIH cells) by MTT Assay. HeLa cells and NIH cells were cultured in Dulbecco's Modified Eagle's Medium (DMEM) while SiHa cells was maintained in Roselle's Park Memorial Institute (RPMI) 1640 medium. Both medium was supplemented with $5 \%$ fetal bovine serum and $1 \%$ penicillin-streptomycin. The cell lines were maintained at $37^{\circ} \mathrm{C}$ in a humidified $5 \% \mathrm{CO}_{2}$ incubator. Briefly, $90 \%$ of confluent cells were seeded overnight prior to treatment in 96 well plates at $5 \times 10^{4}$ cells/well. The F1, F2, F3 and F4 were dissolved in DMSO and followed by a serial dilution ranged from $0.2 \mu \mathrm{g} / \mathrm{mL}$ to $100 \mu \mathrm{g} / \mathrm{mL}$. Cisplatin was used as a positive control and DMSO acted as negative control. The plates were incubated for $72 \mathrm{~h}$ at $37^{\circ} \mathrm{C}$ in a humidified $5 \% \mathrm{CO}_{2}$. At the end of incubation, old medium 
was discarded and $50 \mu \mathrm{L}$ of MTT solution was added to each well. The plates were then incubated for another $4 \mathrm{~h}$. Later, MTT solution was removed and purple formazan formed at the bottom of plates were dissolved with $200 \mu \mathrm{L}$ DMSO. The plates were then shaken for $30 \mathrm{~min}$ and the absorbance at $570 \mathrm{~nm}$ was read on spectrophotometric microplate reader. The percentage of cell viability was calculated as (optical density treated)/(optical density negative control) $\times 100 \%$. Dose response curves were constructed to obtain $\mathrm{IC}_{50}$ values.

\section{PERCENTAGE OF APOPTOSIS EVENT}

The cells were seeded in $25 \mathrm{~cm}^{2}$ flasks under a humidified $5 \% \mathrm{CO}_{2}$ atmosphere at $37^{\circ} \mathrm{C}$ for overnight. The cells concentration for each flask was $5 \times 10^{4}$ cells $/ \mathrm{mL}$. The next day, the cells were treated with $\mathrm{IC}_{50}$ of SF1 and $\mathrm{IC}_{50}$ of cisplatin for 24,48 and $72 \mathrm{~h}$. The untreated cells were used as negative control. After each of incubation period, the SF1-treated, the cisplatin-treated and untreated cells were harvested and collected after centrifuged. The cell pellet was gently rinsed with medium. The tubes were spin at $2000 \mathrm{rpm}$ for $5 \mathrm{~min}$. The cell pellet was washed with cold PBS. The tubes were further centrifuged at 2000 $\mathrm{rpm}$ for $5 \mathrm{~min}$ and re-suspend in $1 \mathrm{X}$ Binding Buffer at a concentration of total cells of $1 \times 10^{6}$ cells $/ \mathrm{mL}$. The cell suspension of $100 \mu \mathrm{L}$ with $1 \times 10^{5}$ cell $/ \mathrm{mL}$ was transfer to flowcytometry tube. Five $\mu \mathrm{L}$ of Annexin V FITC and $5 \mu \mathrm{L}$ of propidium iodide were added to the cell suspension. Each tube was gently vortex and incubated at room temperature in the dark room for $15 \mathrm{~min} .1 \mathrm{X}$ Binding Buffer of $400 \mu \mathrm{L}$ was added and samples were analysed immediately within $1 \mathrm{~h}$. In this assay, three types of control were prepared for compensation of flowcytometry; SiHa cell suspension and propidium iodide; SiHa cell suspension and Annexin V FITC and only SiHa cell suspension.

\section{DETECTION OF APOPTOTIC PROTEIN EXPRESSION}

The cells were seeded in $25 \mathrm{~cm}^{2}$ flasks under a humidified $5 \% \mathrm{CO}_{2}$ atmosphere at $37^{\circ} \mathrm{C}$ for overnight. The cells concentration for each flask was $5 \times 10^{4}$ cells $/ \mathrm{mL}$. The next day, the cells were treated with $\mathrm{IC}_{50}$ of SF1 and $\mathrm{IC}_{50}$ of cisplatin for 24,48 and $72 \mathrm{~h}$. The untreated cells were used as negative control. After each of incubation period, the SF1-treated, the cisplatin-treated and untreated cells were collected after centrifuged. Cells were fixed in ice cold $70 \%$ ethanol. The tubes were gently vortexed for 1 $\mathrm{h}$ at $20^{\circ} \mathrm{C}$. Then, the cell pellet was washed twice with 1 $\mathrm{X}$ PBS and re-suspended in blocking buffer that consist of $2 \%$ bovine serum albumin (BSA) for $10 \mathrm{~min}$. Then, another washing step was carried out. Cell pellet was resuspended in PBS to a concentration of $1 \times 10^{7}$ cells $/ \mathrm{mL}$. Then, $100 \mu \mathrm{L}$ of cells suspension with concentration of $1 \times 10^{6}$ cells $/ \mathrm{mL}$ was transferred into flowcytometry tubes. $20 \mu \mathrm{L}$ of PE conjugated antibody was added into tubes. The Bax-PE conjugated antibody, Bcl-2-FITC conjugated and cytochrome C-PE conjugated were used in this study.
Later, the tubes were maintained for $30 \mathrm{~min}$ in the dark at room temperature. The pellets were washed with $1 \mathrm{~mL}$ of $1 \mathrm{X}$ PBS. The cell pellets were re-suspended in $500 \mu \mathrm{L}$ of $1 \mathrm{X}$ PBS and ready to proceed for flowcytometry analysis.

\section{STATISTICAL ANALYSIS}

Statistical analysis was performed using Graph Pad PRISM Version 6.0 GraphPad Software Inc, California, United States. Each experiment was conducted in triplicate and expressed as mean \pm S.D. Statistical significances of data obtained were calculated and determined using Students' paired t-test or two-way ANOVA with Turkey's multiple comparison tests.

\section{RESULTS AND DISCUSSION}

\section{EXTRACTION, ISOLATION AND PURIFICATION}

All collected fractions with similar TLC profile were combined to afford total of four fractions known as F1, F2, F3 and F4. F1 was obtained as yellowish - green paste while F2 and F3 was in darker green. F4 was obtained in slightly lighter in green colour compared to F2 and F3. The Rf value for each collected fraction were tabulated in Table 1.

TABLE 1. Rf values for each fraction

\begin{tabular}{cc}
\hline Fraction & Rf value \\
\hline F1 & 0.81 \\
F2 & 0.78 \\
F3 & 0.77 \\
F4 & 0.78 \\
\hline
\end{tabular}

\section{CYTOTOXIC ACTIVITY OF SEMI-PURIFIED} FRACTION OF C. nutans

Cytotoxicity is the ability of plants derived compound to arrest the proliferation of cells (Zakaria et al. 2017). In this present study, MTT assay was utilized as cytotoxicity test in order to obtain $\mathrm{IC}_{50}$ values. $\mathrm{IC}_{50}$ value can be defined as half maximal inhibitory concentration in a population $(\mathrm{Ng}$ et al. 2017). United States National Cancer Institute (NCI) plant screening program reported that $\mathrm{IC}_{50}$ value less than $20 \mu \mathrm{g} / \mathrm{mL}$ for extract or fraction, and less than $4 \mu \mathrm{g} / \mathrm{mL}$ for pure compound can be generally considered having cytotoxic properties, in vitro (Boik 2001). This indicator was used as reference value throughout this current study. The lowest $\mathrm{IC}_{50}$ values from all collected fractions against $\mathrm{HeLa}, \mathrm{SiHa}$ and NIH were shown in Table 2. Figure 1(A), 1(B) and 1(C) shows dose response curves of all collected fractions towards HeLa, SiHa and NIH cells, respectively.

There was no remarkable $\mathrm{IC}_{50}$ values were detected on NIH cell proliferation as the $\mathrm{IC}_{50}$ values for all fractions were more than the highest concentration used in this experiment. Zazali et al. (2013) reported that when the $\mathrm{IC}_{50}$ values are more than $99 \mu \mathrm{g} / \mathrm{mL}$ on proliferation of normal 
A

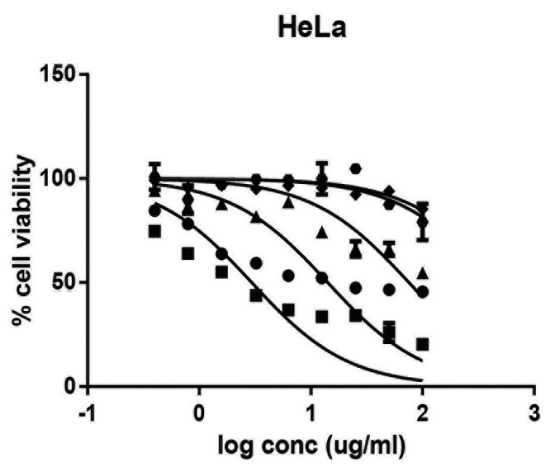

B $\mathrm{SiH}$ a

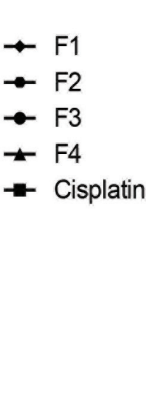

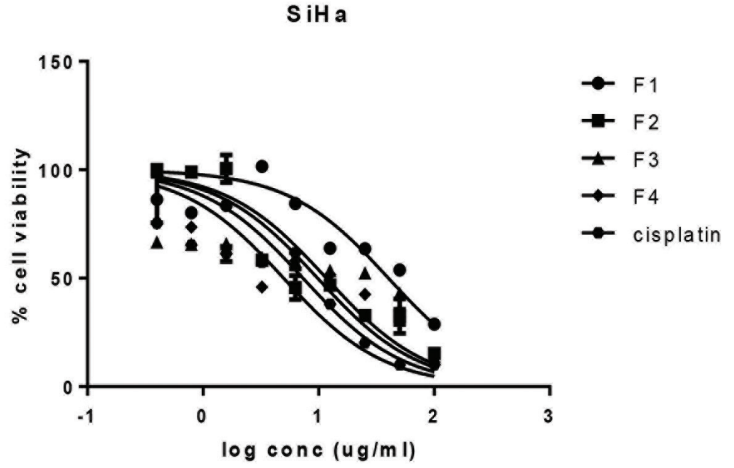

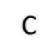

NIH

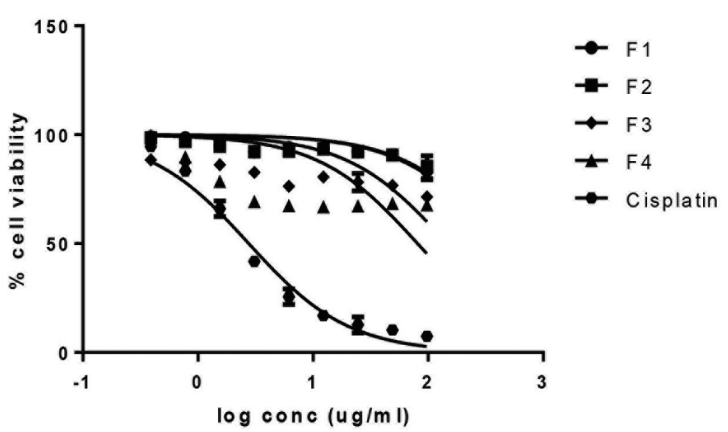

FIGURE 1. Dose response curve of F1, F2, F3, F4 and cisplatin towards (A) HeLa cells, (B) SiHa cells and (C) NIH cells

cells, no inhibition effects are shown. Similar findings also showed that ethyl acetate and methanol roots extract of $C$. nutans showed little inhibition on NIH normal cells which indicated that no harmful effect was detected (Teoh et al. 2016). The positive control, cisplatin, one of commonly use chemotherapy drug for cervical cancers (Zhen et al. 2016) exhibited strong cytotoxic activity on all tested cell line; $2.76 \pm 1.06 \mu \mathrm{g} / \mathrm{mL}$ on NIH cells, $2.95 \pm 1.20 \mu \mathrm{g} / \mathrm{mL}$ on HeLa and $2.29 \pm 1.16 \mu \mathrm{g} / \mathrm{mL}$ on SiHa cells. The main purpose of any anticancer chemotherapy drug is to specifically target on cancer cells without or with minimal effect on normal cells (Jaudan et al. 2018). However, cisplatin failed to achieve this aim due to its action are general, unspecified and cause severe side effects (Huang et al. 2016; Zhen et al. 2016).

Within the four fractions, F3 inhibited growth of HeLa cells with $\mathrm{IC}_{50}$ values $14.16 \pm 1.28 \mu \mathrm{g} / \mathrm{mL}$ while F2, F3 and F4 showed potent inhibition towards SiHa cells with $\mathrm{IC}_{50}$ values $9.81 \pm 1.15 \mu \mathrm{g} / \mathrm{mL}, 11.68 \pm 1.27 \mu \mathrm{g} / \mathrm{mL}$ and 7.33 $\pm 1.23 \mu \mathrm{g} / \mathrm{mL}$, respectively. Other studies reported that $C$. nutans hexane extracts showed $\mathrm{IC}_{50}$ values of $74 \mu \mathrm{g} / \mathrm{mL}$ on lung cancer, A549 and $25 \mu \mathrm{g} / \mathrm{mL}$ on HepG2, liver cancer ( $\mathrm{Ng}$ et al. 2017). To compare with other related studies, the growth of HeLa cells was inhibited when treated with chloroform extract and active fraction of $C$. nutans, respectively (Roslan et al. 2018; Yong et al. 2013). The aqueous extract of $C$. nutans also has showed a cytotoxic effect towards HeLa cell with $\mathrm{IC}_{50}$ value of $13 \pm 0.82 \mu \mathrm{g} /$ $\mathrm{mL}$ without affecting normal cell, Vero (Zakaria et al. 2017). However, in the present findings, most fractions of
C. nutans showed better inhibition and highly sensitive towards $\mathrm{SiHa}$ cells compared to HeLa cells, as lower $\mathrm{IC}_{50}$ values were exhibited. The $\mathrm{SiHa}$ cells showed most effective inhibition (lowest $\mathrm{IC}_{50}$ values) when treated with the fractions of $C$. nutans. Therefore, SiHa cells are more susceptible to $C$. nutans treatment compared to HeLa cells. SiHa cells are cervical squamous carcinoma cell that contains integrated HPV 16 genotype whereas HeLa cells are cervical adenocarcinoma that integrated HPV 18 genotype (Choudari et al. 2013; He et al. 2017). This current study demonstrated potent cytotoxic properties of C. nutans towards SiHa cells. Thus, SiHa cells was selected for further experiments.

Based on the $\mathrm{IC}_{50}$ values obtained, F2, F3 and F4 showed highly inhibition on $\mathrm{SiHa}$ cells as compared to F1. Beside $\mathrm{IC}_{50}$ values, these three fractions displayed similar Rf values. Therefore, F2, F3 and F4 were combined and named as SF1. SF1 was subjected for further experiments for determination of mechanism of cell death. Hence, the average $\mathrm{IC}_{50}$ values of $\mathrm{F} 2, \mathrm{~F} 3$ and $\mathrm{F} 4$ which is $9.60 \mu \mathrm{g} / \mathrm{mL}$ was used in the subsequent experiments.

\section{INDUCTION OF APOPTOTIC CELL DEATH OF SF1}

Mode of apoptotic cell death on SF1-treated SiHa cells was investigated through double staining with Annexin V and propidium iodide (PI). This was carried out in order to determine the mechanism of cell death of SF1 from $C$. nutans against SiHa cells. Figure 2 shows that staining with Annexin V and PI allowed differentiation and quantification 
TABLE 2. The $\mathrm{IC}_{50}$ values of $C$. nutans fractions against $\mathrm{HeLa}, \mathrm{SiHa}$, NIH cells. The values are represented as mean \pm S.D with $* p<0.05$ was taken as significantly different from cisplatin

\begin{tabular}{lccccc}
\hline \multirow{2}{*}{ Cell lines } & \multicolumn{5}{c}{$\mathrm{IC}_{50}$ values $(\mu \mathrm{g} / \mathrm{mL})$} \\
\cline { 2 - 6 } & $\mathrm{F} 1$ & $\mathrm{~F} 2$ & $\mathrm{~F} 3$ & $\mathrm{~F} 4$ & Cisplatin \\
\hline HeLa & $>100$ & $>100$ & $14.16 \pm 1.28^{*}$ & $75.66 \pm 1.15^{*}$ & $2.95 \pm 1.20$ \\
SiHa & $40.22 \pm 1.15^{*}$ & $9.81 \pm 1.15^{*}$ & $11.68 \pm 1.27^{*}$ & $7.33 \pm 1.23^{*}$ & $2.29 \pm 1.16$ \\
$\mathrm{NIH}$ & $>100$ & $>100$ & $>100$ & $80.92 \pm 1.29^{*}$ & $2.76 \pm 1.06$ \\
\hline
\end{tabular}

\begin{tabular}{|c|c|c|c|}
\hline $\begin{array}{l}\text { Duration of } \\
\text { treatment }\end{array}$ & $24 \mathrm{~h}$ & $48 \mathrm{~h}$ & $72 \mathrm{~h}$ \\
\hline
\end{tabular}

SF1
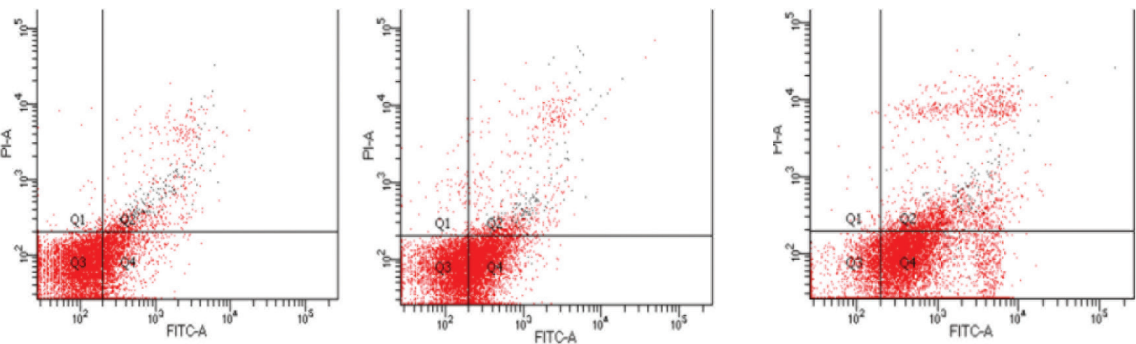

$\mathrm{CP}$
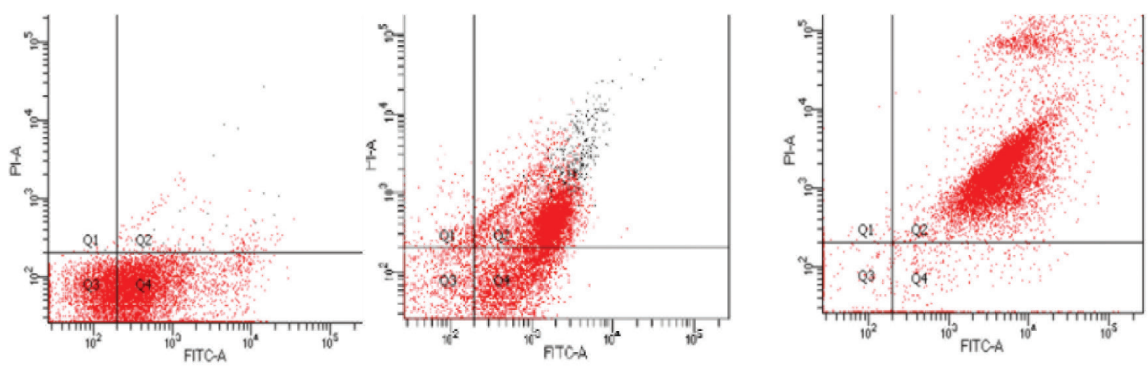

UT
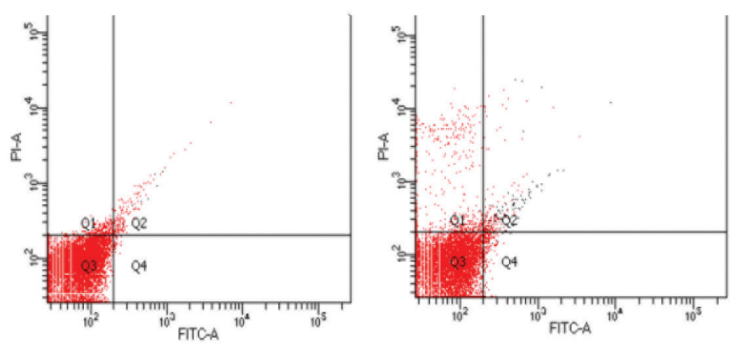

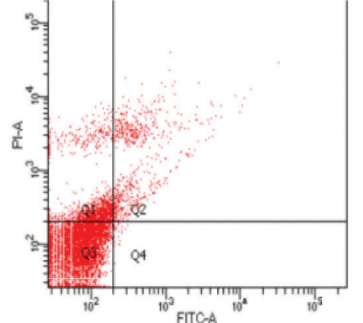

FIGURE 2. Scatter plots of SiHa cells stained with PI/FITC - Annexin V in quadrant analysis; viable cells (Q3), early apoptotic cells (Q4), late apoptotic cells (Q2) and necrotic cells (Q1) in untreated SiHa cells (UT), SF1-treated SiHa cells (SF1) and cisplatin-treated SiHa cells (CP) for 24, 48 and $72 \mathrm{~h}$

of four cell types in four quadrant analysis; Q1 (PI positive, Annexin V negative), Q2 (PI positive, Annexin V positive), Q3 (PI negative, Annexin V negative) and Q4 (PI negative, Annexin V positive). Phosphatidylserine (PS) from inner side of plasma membrane was translocated to outer cell surface thus allow Annexin V binds to the PS during early apoptosis event (Jaudan et al. 2018; Zazali et al. 2013). Subsequently, PI stained DNA of a damaged cell membrane during late apoptosis. Following treatment with $\mathrm{IC}_{50}$ values of SF1 towards $\mathrm{SiHa}$ cells, the percentage of early apoptotic cells (Q4) were significantly increased $(p<0.0001)$ from $20.27 \pm 2.15 \%, 47.03 \pm 4.56 \%$ until $67.70 \pm 2.36 \%$ throughout 24, 48 and $72 \mathrm{~h}$, compared to untreated control group (Figure 3(A) and 3(B)). These findings showed that SF1 was able to induce apoptosis in SiHa cells in a timedependent manner.

The present findings also showed that upon treatment with lower $\mathrm{IC}_{50}$ value towards SiHa cells, SF1 managed to induce apoptosis compared to higher concentration used by other researchers. As example, $\mathrm{Ng}$ et al. (2017) demonstrated that $C$. nutans hexane extract $(150 \mu \mathrm{g} / \mathrm{mL})$ induced apoptosis in CNE1 and HepG2 cells. Meanwhile, Fong et al. (2016) reported that late apoptosis occurred in D24 melanoma cells treated with $2 \mathrm{mg} / \mathrm{mL}$ methanol 
extract of $C$.nutans, hence increased the percentage of late apoptosis and decrease in viable cells at longest treatment time, $72 \mathrm{~h}$. In contrast with positive control drug, cisplatin (Figure 3(C)), the percentage of early apoptosis was 60.20 $\pm 2.17 \%$ after only $24 \mathrm{~h}$ of treatment. However, at $72 \mathrm{~h}$ treatment period, the number of early apoptotic cells were decreased to $4.53 \pm 0.83 \%$. The major population of $\mathrm{SiHa}$ cells-treated cisplatin were detected at late apoptosis (Q2) with $88.07 \pm 5.35 \%$. This was in accordance with Santin et al. (2011) that reported as early as $48 \mathrm{~h}$ of treatment with cisplatin in neuroblastoma cell, there are more than $50 \%$ of late apoptotic cells were shown. In untreated $\mathrm{SiHa}$ cells, the number of viable cells (Q3) were remained high throughout treatment period indicating that cells continuously growth and apoptosis occur as a typical process in cells (He et al. 2017; Zazali et al. 2013). Taken together, SF1 has a capability to trigger early apoptosis event in $\mathrm{SiHa}$ cells within $72 \mathrm{~h}$ treatment period.

\section{DETECTION OF APOPTOTIC PROTEIN EXPRESSION INDUCED BY SF1}

The mechanism of apoptosis pathway in SF1-treated SiHa cells was further examined through determination of Bax,
$\mathrm{Bcl}-2$ and cytochrome $\mathrm{C}$ proteins. The apoptosis pathway can occur via extrinsic or intrinsic pathway (Teoh et al. 2016). In this study, the main focused was on intrinsic pathway where activation of this pathway is regulated by Bcl-2 family proteins such as Bax, pro-apoptotic proteins and Bcl-2, anti-apoptotic proteins (Huang et al. 2015; Zazali et al. 2013). Results indicated that the level of Bax (Figure 4(A)) was increased dramatically as prolonged incubation time with SF1. The Bax levels of $40.90 \pm 2.89 \%, 61.17 \pm 0.80 \%$ and $74.97 \pm 5.69 \%$ were observed throughout $24 \mathrm{~h}, 48 \mathrm{~h}$ and $72 \mathrm{~h}$, respectively. On the contrary from untreated cells, the percentage of Bax were remain low at all treatment hours. The levels of Bcl-2 (Figure 4(B)) were $63.30 \pm 0.60 \%$ at $24 \mathrm{~h}$ and significantly decreased to $56.47 \pm 1.27 \%$ at $48 \mathrm{~h}$ followed by major decrement to $22.33 \pm 3.43 \%$ at $72 \mathrm{~h}$ treatment with SF1 $(p<0.001)$. As compared to untreated cells, the percentage of Bcl-2 were remained higher where more than $90 \%$ population were observed during all incubation time. Throughout $24 \mathrm{~h}$ until $72 \mathrm{~h}$ of SF1 treatment, the expression of cytochrome C (Figure 4(C)) increased gradually from $18.87 \pm 4.16 \%, 47.17 \pm 5.85 \%$ and $81.80 \pm$ $3.25 \%$, respectively. No significant increment can be seen of cytochrome $\mathrm{C}$ levels in untreated cells. The cisplatin-
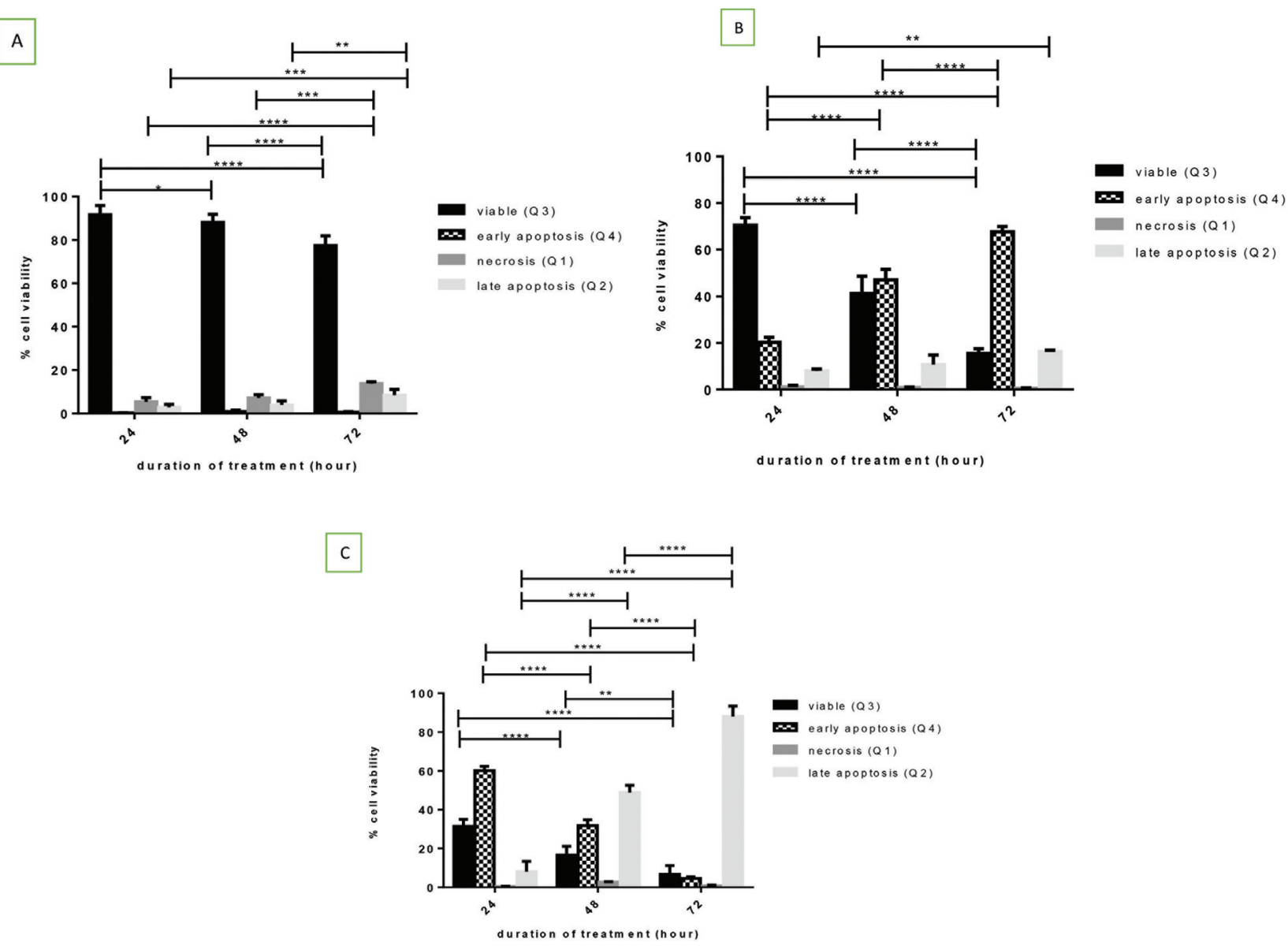

FIGURE 3. Percentage of cell count in each quadrant for (A) untreated SiHa cells, (B) SF1-treated SiHa cells and (C) cisplatin-treated $\mathrm{SiHa}$ cells. Each point represented mean \pm S.D of three independent experiments with $* * * * p<0.0001$, $* * * p<0.001, * * p<0.01$ and $* p<0.05$ were taken as significantly different with treatment duration 

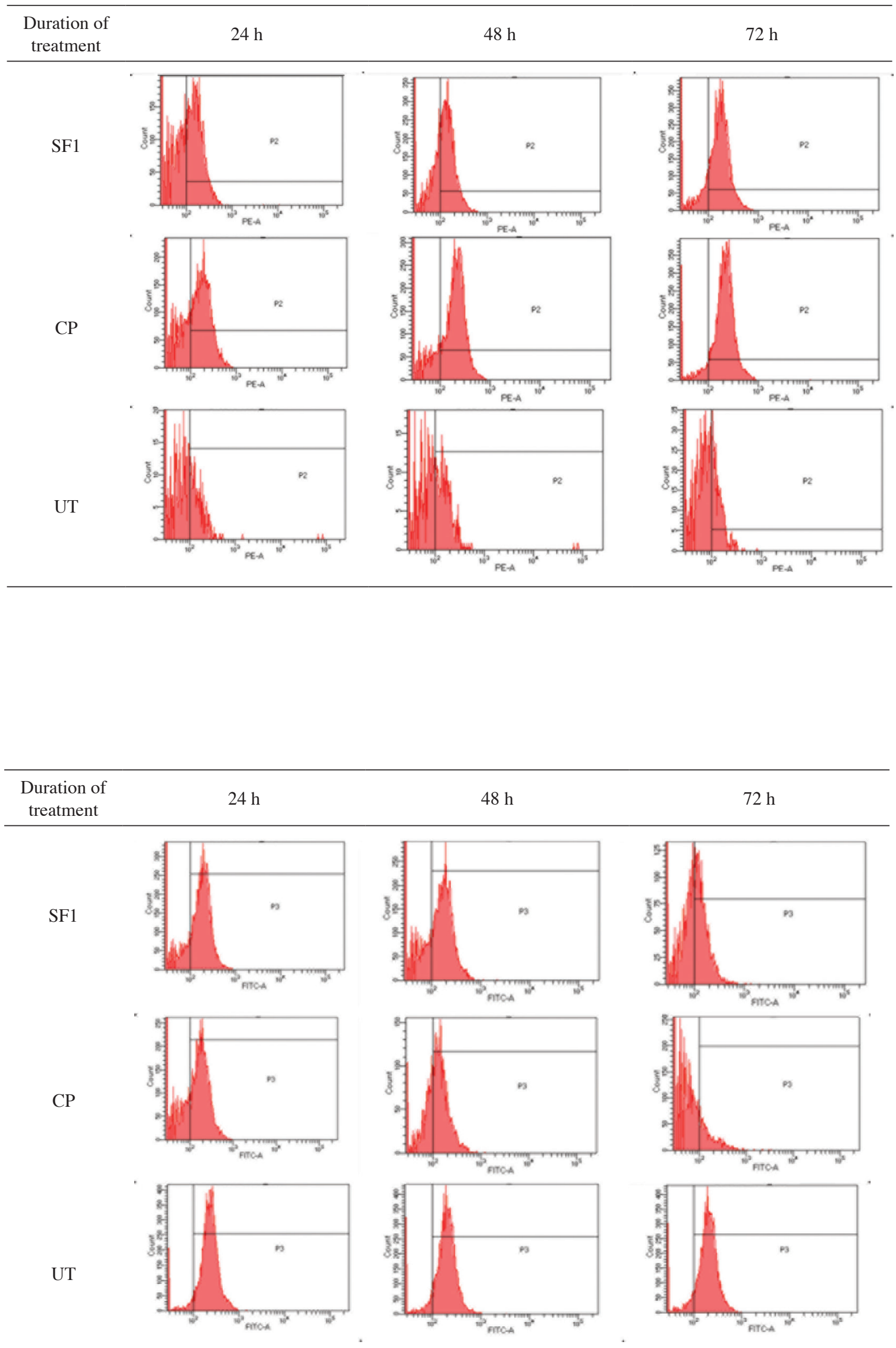


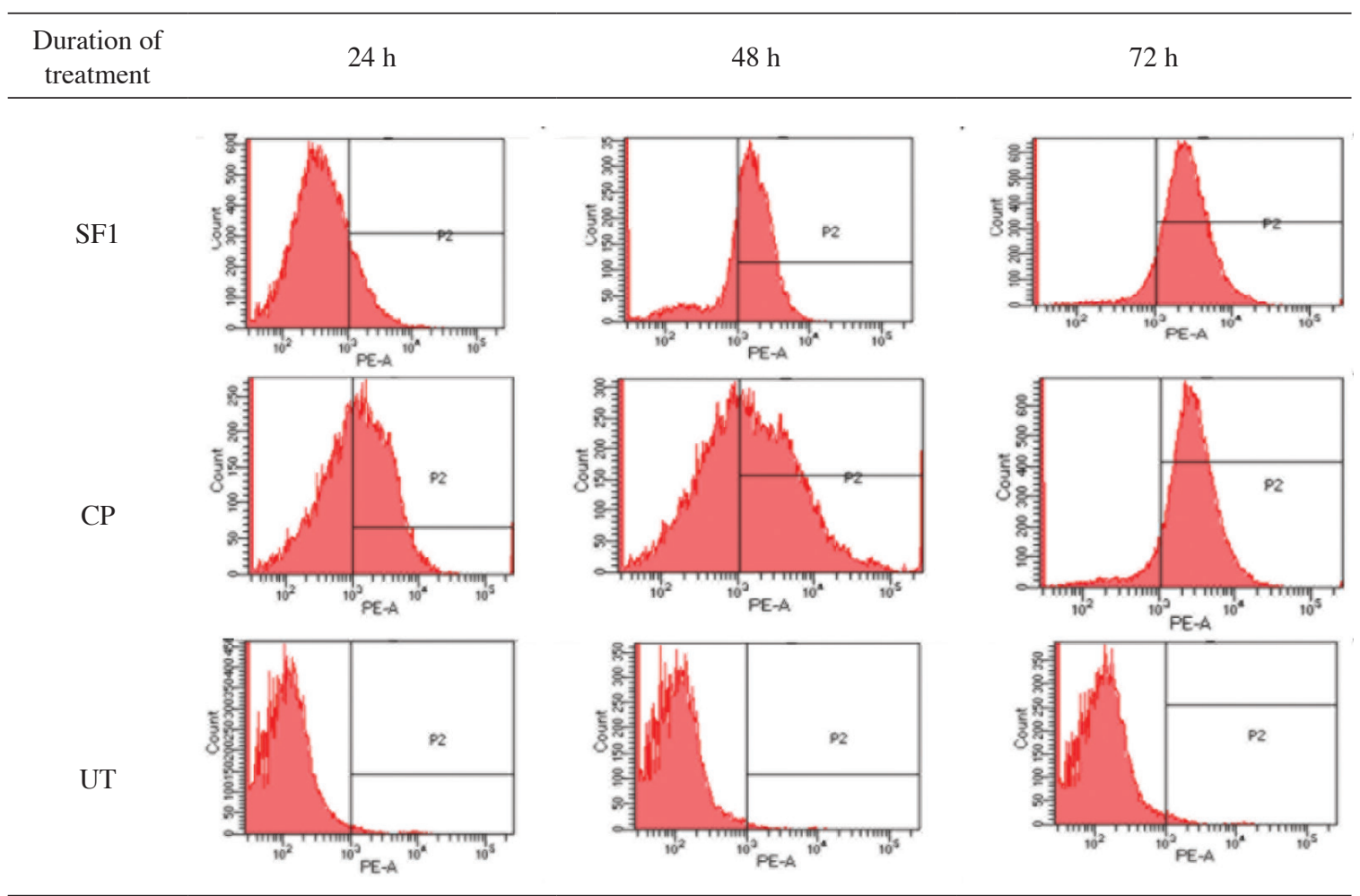

FIGURE 4. Histogram profile of (A) Bax, (B) Bcl-2 and (C) Cytochrome C proteins expression detected by flowcytometry analysis in untreated SiHa cells (UT), SF1-treated SiHa cells (SF1) and cisplatin-treated SiHa cells (CP) for 24 h, 48 h and $72 \mathrm{~h}$

A

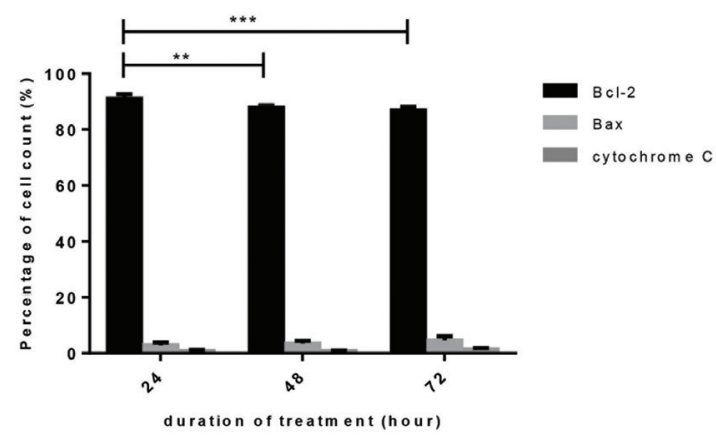

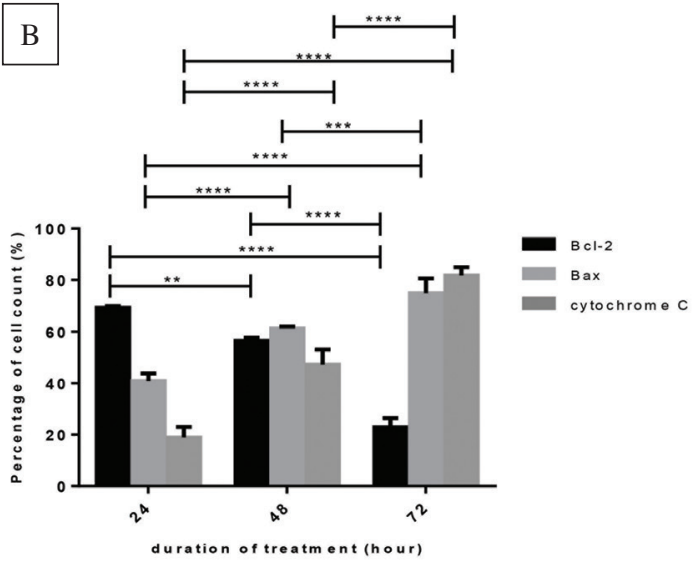

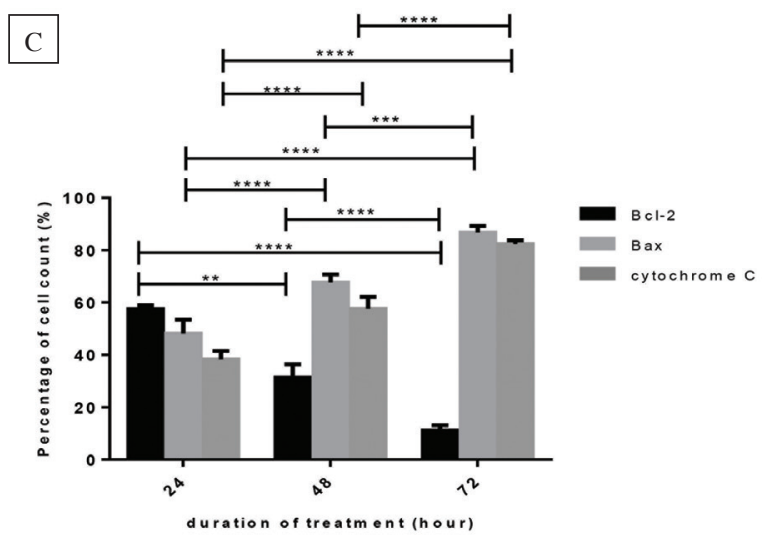

FIGURE 5. Expression levels of Bcl-2, Bax and cytochrome C for (A) untreated SiHa cells, (B) SF1-treated SiHa cells and (C) cisplatin-treated $\mathrm{SiHa}$ cells. The value of bars represented mean $\pm \mathrm{SD}$ of three independent experiment with $* * * * p<0.0001$, $* * * p<0.001$ and $* * p<0.01$ were taken as significant different with the treatment durations 
treated $\mathrm{SiHa}$ cells showed typical increment in expression of Bax and cytochrome $\mathrm{C}$ and decrement of Bcl-2 levels throughout all treatment duration (Figure 5(C)).

The present findings are synchronized with previous studies where Western blot analysis of $30 \%$ ethanol extract from $C$. nutans induced apoptosis in hepatoma cells with increased expression levels of Bax and decreased in Bcl2 expression (Huang et al. 2015). Real-Time Polymerase Chain Reaction (RT-PCR) analysis also showed that ethyl acetate and methanol roots extracts of $C$. nutans promote apoptosis by suppressing the expression of anti-apoptotic gene, Bcl-2 while maintaining the expression of proapoptotic gene, Bax in MCF-7 cells (Teoh et al. 2016). The higher production of Bax in SF1-treated SiHa cells might be activated by p53 thus, stimulating the release of cytochrome $\mathrm{C}$ from mitochondria to cytosol (Chipuk \& Green 2008; Zazali et al. 2013). There are several previous studies demonstrated that apoptosis was induced directly by up-regulation of Bax, down-regulation of Bcl-2 and release of cytochrome $\mathrm{C}$ via mitochondrial pathway in human cervical cancer cells (Huang et al. 2015; JuÈrgensmeier et al. 1998; Xu et al. 2017). Hence, the apoptosis induction in SF1-treated SiHa cells was promoted by action of Bax thus activated the mitochondrial-dependent pathway of apoptosis.

\section{CONCLUSION}

SF1 selectively inhibited the growth of SiHa cells without affecting normal cells. The inhibitory effect of SF1 towards SiHa cells was associated with induction of apoptosis cell death via mitochondrial pathway. Further in vivo studies and identification of responsible anticancer compound will be carried out. Nevertheless, these current findings provide a platform to further explore the mechanism of action of SF1.

\section{ACKNOWLEDGEMENTS}

This research was funded by Research University Incentives (RUI) 1001/PPSK/812165 from Universiti Sains Malaysia (USM), Malaysia. The research was carried out at School of Health Sciences (PPSK) and School of Medical Sciences (PPSP), Universiti Sains Malaysia, Kelantan.

\section{REFERENCES}

Alam, A., Ferdosh, S., Ghafoor, K., Hakim, A., Juraimi, A.S., Khatib, A. \& Sarker, Z.I. 2016. Clinacanthus nutans: A review of the medicinal uses, pharmacology and phytochemistry. Asian Pacific Journal of Tropical Biomedicine 9(4): 402-409.

Boik, J. 2001. Natural Compounds in Cancer Therapy. Minnesota: Oregon Medical Press.

Bruni, L.B.R.L., Albero, G., Serrano, B., Mena, M., Gómez, D., Muñoz, J., Bosch, F.X. \& Sanjosé, S. 2018. Human Papillomavirus and Related Diseases in Asia. ICO/IARC Information Centre on HPV and Cancer (HPV Information Centre), Spain.
Chipuk, J.E. \& Green, D.R. 2008. How do BCl-2 proteins induce mitochondrial outer membrane permeabilization? Trends in Cel. Biology 18(4): 57-164.

Ch'ng, Y.S., Tan, C.S., Loh, Y.C., Ahmad, M., Asmawi, M.Z. \& Yam, M.F. 2016. Vasorelaxation study and tri-step infrared spectroscopy analysis of Malaysian local herbs. Journal of Pharmacopuncture 19(2): 145-154.

Choudari, A.S., Suryavanshi, S.A. \& Kaul-Ghanekar, R. 2013. The aqueous extract of Ficus religiosa induces cell cycle arrest in human cervical cancer cell lines SiHa (HPV-16 positive) and apoptosis in HeLa (HPV-18 positive). PLoS ONE 8(7): e70127.

Fong, S.Y., Piva, T., Dekiwadia, C., Urban, S. \& Huynh, T. 2016. Comparison of cytotoxicity between extracts of Clinacanthus nutans (Burm. f.) Lindau leaves from different locations and the induction of apoptosis by the crude methanol leaf extract in D24 human melanoma cells. BMC Complementary and Alternative Medicine 16: 368.

Ghasemzadeh, A., Nasiri, A., Jaafar, H.Z.E., Baghdadi, A. \& Ahmad, I. 2014. Changes in phytochemical synthesis, chalcone synthase activity and pharmaceutical qualities of Sabah Snake Grass (Clinacanthus nutans L.) in relation to plant age. Molecules 19: 17632-17648.

He, S.H., Liu, H.G., Zhou, Y.F. \& Yue, Q.F. 2017. Liquiritin (LT) exhibits suppressive effects against the growth of human cervical cancer cells through activating caspase-3 in vitro and xenograft mice in vivo. Biomedicine \& Pharmacotherapy 92: 215-228.

Huang, D., Li, Y., Cui, F., Chen, J. \& Sun, J. 2016. Purification and characterization of a novel polysaccharide-peptide complex from Clinacanthus nutans Lindau extracts. Carbohydrate Polymers 137: 701-708.

Huang, D., Guo, W., Gao, J., Chen, J. \& Olatunji, J.O. 2015. Clinacanthus nutans (Burm.f.) Lindau ethanol extract inhibits hepatoma in mice through upregulation of the immune response. Molecules 20: 17405-17428.

Indramalar, S. 2015. No women should die from cervical cancer. The Star Online. 16th Jan.

Jaudan, A., Sharma, S., Malek, S.N.A. \& Dixit, A. 2018. Induction of apoptosis by pinostrobin in human cervical cancer cells: Possible mechanism of action. PLoS ONE 13(2): 0191523.

JuÈrgensmeier, J.M., Xie, Z., Deveraux, Q., Ellerby, L., Bredesen, D. \& Reed, J.C. 1998. Bax directly induces release of cytochrome $\mathrm{C}$ from isolated mitochondria. Proceedings of the National Academy of Sciences of the United States of America 95: 4997-5002.

Le, C.F., Kailaivasan, T.H., Sek-Chuen, C., Zunoliza, A., SuiKiong, L. \& Chee-Mun, F. 2017. Phytosterols isolated from Clinacanthus nutans induce immunosuppressive in murine cells. International Immunopharmacology 44: 203-210.

Ng, P.Y., Soi, M.C., Liew, P.P., Chew, H.N., Yong, H.T., Rhun, Y.K., Crystale, S.Y.L., Khuen, Y.N. \& Yee, L.T. 2017. Clinacanthus nutans hexane extracts induce apoptosis through a caspase-dependent pathway in human cancer cell lines. Asian Pacific Journal of Cancer Prevention 18(4): 917-926.

Roslan, S.N.F.M., Yusmazura, Z. \& Hasmah, A. 2018. Cytotoxicity of Clinacanthus nutans and mechanism of action of its active fraction towards human cervical cancer cell line, HeLA. Jurnal Sains Kesihatan Malaysia 16(2): 39-50.

Sakdarat, S., Shuyprom, A., Pientong, C., Ekalaksananan, T. \& Thongchai, S. 2009. Bioactive constituents from the leaves 
of Clinacanthus nutans Lindau. Bioorganic \& Medicinal Chemistry 17: 1857-1860.

Santin, G., Piccolini, V.M., Veneroni, P., Barni, S., Bernocchi, G. \& Bottone, M.G. 2011. Different patterns of apoptosis in response to cisplatin in B50 neuroblastoma rat cells. Histology and Histopathology 26: 831-842.

Sulaiman, I.S.C., Basri, M., Chan, K.W., Ashari, S.E., Masoumi, H.R.F. \& Ismail, M. 2015. In vitro antioxidant, cytotoxic and phytochemical studies of Clinacanthus nutans Lindau leaf extracts. African Journal of Pharmacy and Pharmacology 9(34): 861-874.

Teoh, P.L., Cheng, A.Y.F., Liau, M., Lem, F.F., Kaling, G.P., Chua, F.N. \& Cheong, B.E. 2016. Chemical composition and cytotoxic properties of Clinacanthus nutans root extracts Pharmaceutical Biology 55(1): 394-401.

World Health Organization. 2017. http://apps.who.int/ medicinedocs/en/d/Jh2945e/2.1.html. Accessed on 6 June 2017.

Xu, W., Mi, Y., He, P., He, S. \& Niu, L. 2017. $\gamma$-Tocotrienol inhibits proliferation and induces apoptosis via the mitochondrial pathway in human cervical cancer HeLa cells. Molecules 22: 1292-1299.

Yong, Y.K., Tan, J.J., Teoh, S.S., Mah, S.H., Ee, G.C.L., Chiong, H.S. \& Ahmad, Z. 2013. Clinacanthus nutans extracts are antioxidant with antiproliferative effect on cultured human cancer cell lines. Evidence-Based Complementary and Alternative Medicine 2013: 462751.

Zakaria, Y., Yee, L.W. \& Hassan, N.F.N. 2017. Anti-cancer effects of Clinacanthus nutans extract towards human cervical cancer cell line, HeLa. Journal of Biomedicine \& Clinical Science 2(1): 11-19.

Zazali, K., Abdullah, H. \& Jamil, N. 2013. Methanol extract of Oroxylum indicum leaves induces G1/S cell cycle arrest in HeLa cells via p53-mediated pathway. International Journal of Medicinal Plant Research 2(7): 225-237.
Zhen, S., Lu, J.J., Wang, L.J., Sun, X.M., Zhang, J.Q., Li, X., Luo, W.J. \& Zhao, L. 2016. In vitro and in vivo synergistic therapeutic effect of cisplatin with human papillomavirus16 E6/E7 CRISPR/Cas9 on cervical cancer cell line. Translational Oncology 9(6): 498-504.

Nik Aina Syazana Nik Zainuddin, Nik Fakhuruddin Nik Hassan \& Yusmazura Zakaria*

School of Health Sciences

USM Health Campus

16150 Kota Bharu, Kelantan Darul Naim Malaysia

Hussin Muhammad

Herbal Medicine Research Centre

Institute for Medical Research (IMR)

50588 Kuala Lumpur, Federal Territory

Malaysia

Nor Hayati Othman

School of Medical Sciences

USM Health Campus

16150 Kota Bharu, Kelantan Darul Naim

Malaysia

*Corresponding author; email: yusmazura@usm.my

Received: 29 October 2018

Accepted: 22 July 2019 